1st. Dept. of Oral Surg. (Director: Prof. I. NAGAI) and 2nd. Dept. of Oral Surg. (Director: Prof. K. KAWAKATSU), Dental School, Osaka Univ., Joan-cho, Kita-ku, Osaka.

\title{
Histochemical Studies of Esterase Activity in the Developing Teeth.*
}

\author{
ラット発育㐘牙に於ける Esterase 活性について。 \\ Wataru YOSHIOKA, Masahiko MORI, Tsuneo MIZUSHIMA \\ and Takeo AMATSU.
}

吉岡済, 森昌彦, 水島恒雄, 天津武男.

(Received August 14, 1960.)

NACHLAS and SELIGMAN (1949) introduced the coupling azo-dye method by the use of $\beta$-naphthyl acetate for the histochemical demonstration of esterase and GOMORI (1953) et al. have reported concerning the simultaneous coupling azo-dye mthod using lipoid ester as the sbstrate. On the other hand, the technique using indoxyl compound as the substrate was revealed by HOLT et al. $(1952,1956,1958)$. PEARSON and DEFENDI (1957) and PEARSON and GROSEL (1959) reported the method utilizing 5-bromoindoxyl acetate. There is only a report by BURSTONE (1957, 1958) concerning the esterase activity in the developing tooth and bone. Particularly the histochemical demonstration of esterase in the developing tooth has, so far, hardly been made.

\section{Materials and Methods.}

Rat fetuses from 15 days to full term and 3 days after birth were obtained from the animals of Wister strain. The head was removed from the fetus and new born rat, and the mandible separated from the rest of the head.

As mentioned at previous work, fresh tissues were cut into thin sections of $10 \mu$ in the cryostat at $-20^{\circ} \mathrm{C}$, and were fixed in $10 \%$ buffered formalin for 10 minutes and rinsed briefly in distilled water. For the simultaneous coupling azo-dye method the following mixture was used.

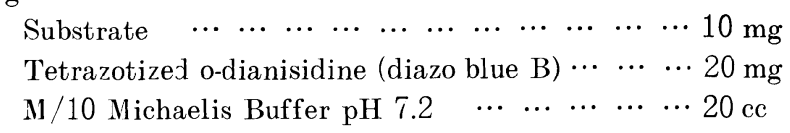

As the substrate, $\boldsymbol{\alpha}$ and $\beta$-naphthyl acetate, napthyl AS acetate, $\beta$-naphthyl myristrate, $\beta$-naphthyl stearate and $\beta$-naphthyl laurate were used, and each naphthyl substrate after dissolution into $1 \mathrm{cc}$ acetone were added $20 \mathrm{cc}$ buffer. Lastly the sections were incubated for an hour at $20^{\circ} \mathrm{C}$ immediatly after added the dye coupler.

We utilized the indigo blue method of PEARSON \& DEFENDI (1957) and PEARSON \& GROSEL (1959), in which indoxyl compound was used as a substrate.

\footnotetext{
* This report was presented at the 14th Congress of Japanese Stomatological Society in May 1960 and 1st Symposium of Japanese Histochemical Society in July 1960.
} 
The following mixture was used.

$$
\begin{aligned}
& \text { 5-bromoindoxyl acetate } \quad \begin{array}{llllllll} 
& \cdots & \cdots & \ldots & \cdots & \cdots & 5 \mathrm{mg} & \text { (in } 1 \mathrm{cc} \text { ethanol.) }
\end{array} \\
& 0.005 \mathrm{M} \text { ferricyanide } \cdots \cdots \cdots \\
& 0.005 \mathrm{M} \text { ferrocyanide } \begin{array}{llllllll} 
& \ldots & \ldots & \ldots & \ldots & \ldots & \ldots & 3 \mathrm{ml}
\end{array} \\
& \mathrm{M} / 10 \text { acetate buffer } \mathrm{pH} \begin{array}{llllll}
5.8 & \ldots & \ldots & \ldots & \cdots & 8 \mathrm{ml}
\end{array}
\end{aligned}
$$

The sections were incubated for 30 minutes at $37^{\circ} \mathrm{C}$ and mounted balsam after dehyd. ration.

Influence of inhibitor: The sections were immersed in $0.01 \mathrm{M}$ sodium fluoride, sodium taurocholate and physotigmine (eserine) for 3 hours at room temperature.

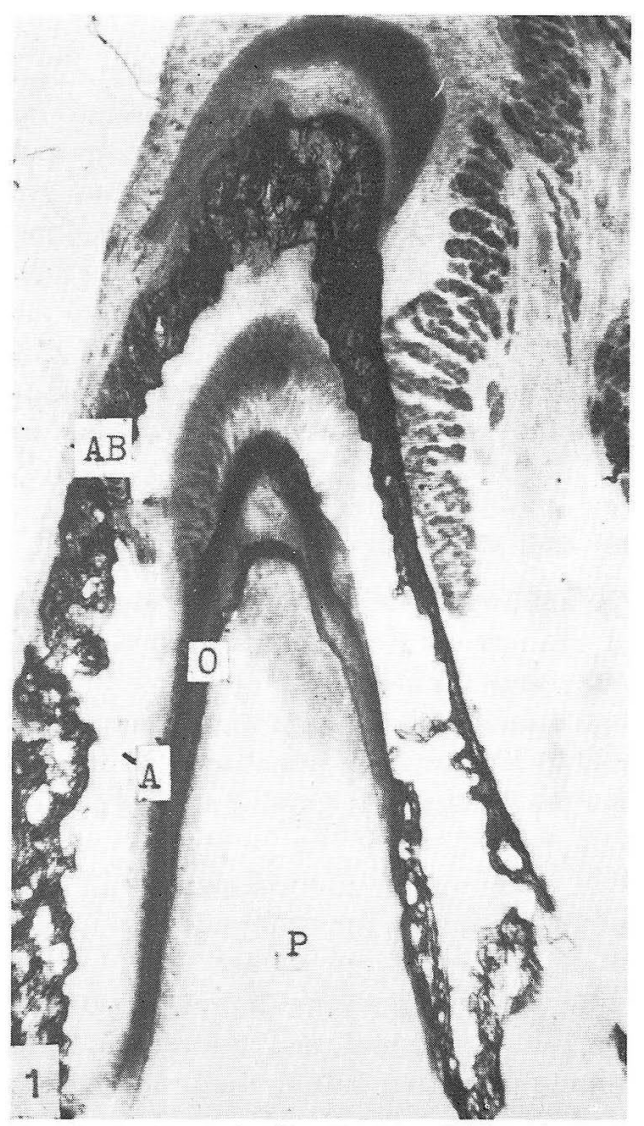

The figure shows the distribution of esterase in the developing tooth and bone. The esterase is of a high activity in the odontoblasts, ameloblasts, calcifying dental hard tissues and alveolar bone, and only a very slight activity in the pulp adjacent to the odontoblasts and reduccd enamel organ. $\times 10$

$A$ ameloblasts, $A B$ alveolar bone, $O$ odontoblasts, $P$ Pulp.

\section{Results.}

In the developing tooth of the fetal and new born rats, esterase high activity was showed intensely in the pre-dentine and the calcifying enamel an increasing amount of the activity throughout the whole of their cytoplasm in the matured odontoblasts and ameloblasts of the anterior dental sac.

There were moderate reaction diffusely in the reduced enamel organ and the narrow basal part of pulp tissue. The undifferentiated odontoblasts and ameloblasts of the anterior and molar teeth showed no strong enzyme activity. The general pulp tissue showed only a very slight amount of staining. There was a staining of the developing alveolar bone and the immatured bone surrounding tooth in dark blue. In our histochemical demonstration of the esterase, the pattern of its distribution indicated exactly the most intense reaction when $\beta$-naphthyl acetate was employed as the substrate, but showsd some diffusion artifacts. Naphthyl AS acetate well conserved the localization of the esterase. The other $\beta$-naphthyl compounds were not so worthy as 
these two substrates. But the localization of the esterase in the developing tooth and bone showed a similar trend in the use of any substrate. In the effect of inhibitor, sodium taurocholate and eserin showed a certain degree of the inhibitive reaction.

\section{Discution.}

It has been reported by only BURSTONE that in the developing tooth and bone, the histochemical study of esterase was made. According to the report by BURSTONE (1957), in which was studied by the use of the coupling azo-dye method as the substrates with five kinds of naphthyl AS acetate, the pre-dentine had no any reaction and the portion of its connencted calcification showed a positive reaction as same as that of the enamel matrix. The localization and the reactive intensity of the esterase activity at present study showed the almost similar trend with acid phosphatase $(\mathrm{pH}$ 5.8 ) by using the simultaneous coupling azo-dye method. The intense reaction of both esterase and acid phosphatase was present in the calcifying dental hard tissues, and in the matured odontoblasts and ameloblasts but not in the undifferentiated cells. This would suggest that the esterase activity has intimate relation to either calicification or the formation of the organic matrix as well as that of acid phosphatase.

NACHLAS and SELIGMAN used $\beta$-naphthyl acetate as the substrate in the histochemical demonstration of esterase. CHESSICK (1953) mentioned that $\beta$-naphthyl acetate is reacted for first several minutes and $\alpha$-naphthyl acetate is reacted for a longer period, and that the diffusion artifact takes place by $\beta$-naphthyl acetate. There are many lipoid and naphthyl compounds which are employed for the azo-dye method of esterase. A significant difference of the localization of esterase was not seen. This was the same as that of GOMORI (1955) and BURSTONE (1956).

In general, the esterase is able to decompose the lower lipoid ester and a part of adipose is also the same. As regards it must be difficult to differentiate definitely the esterase and lipase. BARNETT and SELIGMAN (1951) introduced that there are three types of carbonic acid esterase: first, the decompose the ester of long-chain lipoid and it is accelerated by sodium taurocholate, second, non-specific esterase effects to the ester of short-chain lipoid and it is inhibited by sodium taurocholate, third, there is cholinesterase. At present study, the esterase of the developing tooth and bone was inhibited to a certain extent and not stimulated. It seems to be nonspecific genuine esterase.

On the other method, which has been used by PEARSON and DEFENDI (1957) and PEARSON and GROSEL (1959) in the histochemical demonstration of esterase, 5-bromoindoxyl acetate, and the concentration of $0.005 \mathrm{M}$ of potassium ferricyanide and potassium ferrocyanide were useful. Indigo blue method, which employed 5bromoindoxyl acetate as the substrate, was exactly the same as the simultaneous coupling azo-dye method in the distribution and localization of esterase.

\section{Summary.}

The histochemical demonstration of esterase was made in the developing tooth of the rat by using principally both the simultaneous coupling azo-dye method employed various naphthyl compounds as the substrate and the indigo blue method emp- 
loyed 5-bromoindoxyl acetate.

1. The localization of esterase in the developing tooth showed a high activity in the odontoblasts, ameloblasts, calcifying dental hard tissues and alveolar bone, and only a very slight activity in the pulp adjacent to the odontoblasts and reduced enamel organ. Thus esterase activity has shown the analogous distribution and localizalion to those of acid phosphatase.

2. The simultaneous coupling azo-dye method employed various naphthyl compounds as the substrates showed a similar localization of esterase activity to that by the use of 5-bromoindoxyl acetate method in the developing tooth and bone, however, the method using $\beta$-naphthyl acetate and naphthyl AS acetate as the substrate gained the best result.

3. The esterase activity in the developing tooth and bone of the rat was inhibited to a certain extent for the use of sodium taurocholate and eserin.

4. This was suggested that the esterase activity may be related to the final calcification of the dental hard tissue.

\section{内 容 自 抄.}

ラットの発育しつつある歯牙において esterase の組織化学的研究を租々の naphthol 結合体を基質とした azo 色系結合法と 5-bromoindoxyl acetate を用いた indigo blue 法により証明した.

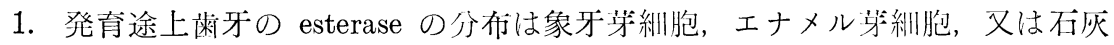

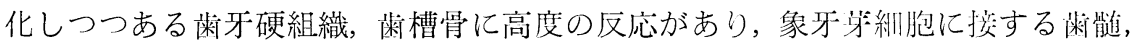
退縮エナメル器にもごく僅かな活性がみられた。

2. 種々の Naphthol 誘導体を用いる azo 色䒺結合法と indigo blue 法とでは esterase の分布は略同様であるが， $\beta$-naphthyl acetate と Naphtl AS acetate を基 質とした方法が最も良好である。Indoxyl 法においては明らかな䦌在性を示さな かった。

3.との esterase 反応は sodium tauroeholate と eserin によりある程度抑制され た.

4. Esterase の分布は酸性 phosphataseのそれに類似し, 硬組織形成と阔係が ある。

\section{References.}

Barrnett, R. J. and A. M. Seligman : Histochemical demonstration of esterases by production of indigo. Science 114 (1951). P. 579-582. - Burstone, M. S.: Esterase of the salivary glands. J. Histoceem. Cytochem. 4 (1956). P. 130-139. - Esterase activity of developing bones and teeth. Arch. Path. 63 (1957). P. 164-167. - Enzymatic associated with calcification. (Abst.) Dent. Res. 37 (1958). P. 5. - Burstone, M. S. and P. H. Keyes : Studies on calcification. I. The effect of inhibition of enzyme activity on developing bone and dentine. Amer. J. Path. 33 (1957). P. 1229-1235. - Bear, P. N. and M. S. Burstone: Esterase activity associated with formation of deposits on teeth. (Abst) J. dent. Res. 38 
(1959). P. 710; Oral Surg. Oral Med. Oral Path. 12 (1959). P. 1147. - Chessick, R. D.: Histochemical study of the distribution of esterases. J. Histochem. Cytochem. 1 (1953). P. 471485. - Gomori, G.: Human esterases. J. Lab. clin. Med. 42 (1953). P. 445-453. - Histochemistry of hnman esterases. J. Histochem. Cytochem. 3 (1955). P. 479-484. Holt, S. J.: A new principle for the histochemical localization of hydrolytic enzymes. Nature 169 (1952). P. 271-273. - The value of fundamental studies of staining reaction in euzyme histochemistry with reference to indoxyl methods for esterases. J. Histochem. Cytochem. 4 (1956). P. 541554. - Holt, S.J. and R. F. T. Withere : Cytochemical localization of esterases using indoxyl derivatives. Nature 170 (1952). P. 1012-1014. - Studies in enzyme cytochemistry. V. An appraisal of indigogenic reactions for esterase localization. Proc. Roy. Soc. 148 (1958). P. 520-532. - Nachlas, M. M. and A. M. Seligman : The histochemical demonstration of esterase. T. Nat. Cancer Inst. 9 (1949). 415-425. The comparative distribution of esterase in the tissues of five mammales by histochemical technique. Anat. Rec. 105 (1949). P. 677 695. - Pearson, B. and V. Defendi : A comparison between the histochemical demonstration of non specific esterase activity 5bromo indoxyl acetate, $\alpha$-naphthyl acetate and naphthol AS acetate. J. Histochem. Cytochem. 5 (1957). P. 72-83. - Pearson, B. D. and F. Grosel,: Further histochemical studies of esterase by 5-bromoindoxyl acetate. Arch. Path. 67 (1959). P. 324-332. 